(demonstrations.wolfram.com) [4]. Окремі Інтернет-базовані різнорівневі і класифіковані за тематикою демонстрації були частково адаптованими нами до потреб візуалізації навчального процесу на рівні лекційного забезпечення та на рівні проведення аудиторних занять й організації самостійної роботи студентів.

Методично привабливим аспектом застосування інтерактивних демонстрацій $\epsilon$ альтернативність, - одна і та ж навчальна проблема може бути проілюстрована різними демонстраціями із бази знань. Окрім того, в подальшому привабливим може стати вивчення й аналіз програмного коду, який є відкритим і забезпечує інтерактивність демонстрацій.

Другий етап упровадження має супроводжуватись розрахунковими прикладами (завданнями) і має пряме відношення до спрощення й оптимізації процесу розв'язування прикладних задач 3 математики. Wolfram Mathematica має також опцію відтворення покрокового розв'язку, що стане в пригоді під час самостійної роботи студента. Опція реалізована в проекті WolframAlpha і є доступною в онлайн-версії та мобільних пристроях. На третьому етапі поєднуються: трансляція та структуризація; спрощення й оптимізація; візуалізація та розпізнавання проблем.

Запропонована технологія $€$ інноваційною для освіти та має відношення до когнітивних методів навчання; у перспективі $\epsilon$ актуальною як інструмент наукового дослідження. Упровадження в навчальний процес математичних демонстрацій-моделей i формування на їх основі інтерактивних навчальних матеріалів є оптимальним з точки зору спрощення, структуризації, стандартизації, візуалізації навчального матеріалу. Запропонована методика використання програмних засобів комп'ютерної математики в навчальному процесі відповідає сучасній концепції науки нового типу - A New Kind of Science [5].

\title{
Література
}

1. Лалак Н. В. Інтерактивна модель навчання студентів: проблеми та перспективи / Н. В. Лалак / Науковий вісник Ужгородського національного університету. - 2011. - № 20. С. 69-70. 2. Пометун О. І. Сучасний урок. Інтерактивні технології навчання : [наук.-метод. посібн.] / О.І.Пометун, Л.В.Пироженко ; за ред. О.І.Пометун. - Київ : Видавництво А.С.К., 2004. - 192 с. 3. Прокопченко О. С. Аксіоми дистанційної, Інтернет базованої навчальної системи та прояв нових тенденцій у розвитку українського освітнього простору / О. Є. Прокопченко // Актуальні питання фармацевтичної та медичної науки та практики : [зб. наук. статей] / за ред. Ю. М. Колесника [та ін.]. - Запоріжжя, 2006. - Вип. 16. - С. 45-51. 4. Prokopchenko O. Sampling Statistics and Statistical Estimation [Електронний ресурс]/ O. Prokopchenko. - Режим доступу: http:// demonstrations.wolfram.com/SamplingStatistics And StatisticalEstimation. 5. Wolfram S. A New Kind of Science / S. Wolfram. - Wolfram Media, Inc., $2002-1192 \mathrm{p}$.

УДК 808.5:811.162.1

Оксана Ранюк

\section{ФОРМУВАННЯ РИТОРИЧНОЇ КОМПЕТЕНЦЇ̈ СТУДЕНТІВ-ФІЛОЛОГІВ ПІД ЧАС ВИВЧЕННЯ ПОЛЬСЬКОЇ МОВИ}

Ранюк О. П. Формування риторичної компетенції студентів-філологів під час вивчення польської мови.

У статті теоретично обгрунтовано поняття «компетенції» та «риторичної компетенції». Зазначено, як можна використовувати риторичний елемент під час вивчення 
польської мови. Представлено систему вправ та завдань на заняттях польської мови, спрямованих на формування риторичної компетенції.

Ключові слова: філолог, риторика, комунікативна компетенція, риторична компетенція, компетентність.

Ранюк А. П. Формирование риторической компетенции студентов-филологов при изучении польского язика.

В статье теоретически обосновано понятие «компетенции» и «риторической компетенции». Отмечено, как можно использовать риторический элемент при изучении польского языка. Представлена система упражнений и заданий на занятиях польского языка, направленных на формирование риторической компетенции.

Ключевые слова: филолог, риторика, коммуникативная компетенция, риторическая компетенция, компетентность.

Raniuk O. P. Forming rhetorical competence of students-philologists in teaching polish language.

The defenitions «competence» and «rhetorical competence» are theoretically grounded in the article. It is specified how to use rhetorical element in teaching polish language. The system of tasks and exercises aimed at forming rhetorical competence at the lessons of polish language is shown.

Key words: philologist, rhetoric, communicative competence, rhetorical competence, competence.

Вища освіта спрямована на формування фахової культури, важливими складникам якої, безумовно, є мовна компетентність і комунікативна досконалість. У процесі здобуття вищої освіти необхідним стає опанування поняттєвого апарату обраної спеціальності.

На сучасному етапі підготовки фахівців в Україні актуалізована проблема філологічної освіченості. Важливою $є$ гармонізація професійних знань i належна мовна/мовленнєва освіченість як фундаментальний складник професіоналізму в комунікативно-діяльнісній сфері гуманітарної галузі.

Процеси реформації в освіті України пов'язані 3 підвищенням компетентнісної спрямованості навчання, передусім філологів. Компетентнісний підхід є стрижневою, базовою ідеєю реформування навчально-виховного процесу в сучасному освітньому середовищі.

Науковці й педагоги-практики розробляють ефективні моделі та технології формування компетентностей у процесі навчання. Однак нині в Україні відсутні розробки оптимальних шляхів формування риторичної компетентності студентів-філологів під час вивчення польської мови, також проблема риторичної компетентності в цьому руслі опрацьована недостатньо, адже польська мова у ВНЗ України почала вивчатися відносно недавно порівняно 3 іншими мовами. 3 огляду на зазначене уважасмо тему статті актуальною.

Риторику як науку і мистецтво слова вивчала велика кількість науковців, зокрема В. Аннушкін, М. Бахтін, Н. Іпполітова, Є. Клюєв, Л. Мацько, Г. Сагач, Ю. Рождественський та ін. У їхніх працях висвітлено основні риторичні категорії й поняття, лінгвістичні основи риторики. Лінгводидакти Н. Голуб, О. Горошкіна, Г. Бондаренко, Г. Дегтярьова, О. Залюбівська, С. Омельчук, Г. Онуфрієнко, М. Пентилюк, Т. Симоненко та інші розробили 
методичні аспекти вивчення риторики на всіх рівнях мовної освіти.

Метою статmі є означення поняття «риторична компетентність» студентівфілологів, окреслення структурних складників риторичної компетентності студентів під час вивчення польської мови.

Для того, щоб з'ясувати поняття «риторична компетенція», варто розглянути зміст понять «компетенція» та «компетентність». За останні десятиліття з'явилася велика кількість робіт, у яких використовують зазначені терміни.

У довідковій літературі термін «компетенція» (від лат. competere - бути здібним до чого-небудь) трактується як кваліфікований, той, що знає, як коло проблем, у яких $є$ обізнаною ця особа, а термін «компетентний» - як той, хто володіє компетенцією. Ці поняття широко використовуються в педагогіці, лінгводидактиці, психології і соціології вітчизняними та зарубіжними науковцями. У психологічній літературі компетентність розглядається як категорія оцінювальна, яка характеризує людину як суб'єкт спеціалізованої діяльності, що дозволяє раціонально й успішно досягати поставлених цілей.

У дослідженні ми використовуватимемо визначення понять «компетентність» та «компетенція» Є. Артамонової. За її словами, компетентність - це інтегративне утворення особистості, яке складається із взаємодії різноманітних компетенцій людини, які формуються та розвиваються у процесі засвоєння теоретичного та практичного досвіду та діяльності. Відповідно, компетенція $є$ вихідною від компетентності і $\epsilon$ певною сферою знань, навичок, умінь та якостей, які в комплексі допомагають людині діяти в різних, у тому числі й у нових для неї ситуаціях [1, с. 12].

У студентів-філологів у процесі вивчення польської мови важливим $є$ формування насамперед комунікативної компетентності, яка передбачає наявність професійних знань, загальної гуманітарної культури людини, умінь і навичок спілкування. Вона формується на основі комунікативної компетенції.

Комунікативна компетенція (лат. competens - відповідний) - це сукупність знань про спілкування в різноманітних умовах і з різними комунікантами, а також уміння ефективно застосовувати ці знання в конкретному спілкуванні [2, с. 162].

Проте важливим елементом професійної мовно-комунікативної компетенції $\epsilon$ володіння основами риторичних знань і вмінь. Саме вони допомагають у становленні людини як цінної для суспільства особистості, професійному зростанню, гармонізації особистісного, професійного й суспільного діалогу. Поняття «риторика» охоплює широкий спектр знань, умінь і навичок: від виникнення ідеї до безпосереднього процесу мовлення. Риторична компетенція - це вміння управляти мисленнєво-мовленнєвою діяльністю, знання механізмів цієї діяльності. На думку Г. Онуфрієнко, риторична компетентність є логічною ланкою у філологічній парадигмі фахової освіти в сучасній Україні. Відсутня або недостатньо сформована риторична компетенція помітно знижує рейтинг фахівця, позбавляючи його професійної перспективи, оскільки знання 3 риторики як лінгвокультурологічної науки й мистецтва ефективної усної переконувальної комунікації (завданням професійного діалогу/полілогу є переконання, котре досягається аргументацією), безперечно, становить фундамент освіченості та професіоналізму.

Формування риторичної компетенції $є$ важливим елементом підготовки майбутніх філологів польської мови. Насамперед вивчення польської мови - це вивчення іноземної мови, що має свою специфіку порівняно $з$ рідною мовою. Важливим $є$ те, що однією 3 найпоширеніших проблем серед тих, хто вивчає іноземну мову, $є$ страх говорити нею, адже студенти хвилюються, що вимовлять те чи інше слово неправильно, і це зумовить осуд серед 
оточення. Саме тому у ВНЗ необхідно наполягати викладачам-полоністам на тому, щоб студенти вчилися розмовляли польською мовою для набуття досвіду.

Оскільки польська мова належить до слов'янських мов, то має багато подібного 3 іншими мовами, наприклад, російською, українською, через це можуть виникнути непорозуміння. Для прикладу: оwосе - фрукти, zapomnic - забути, pensja - зарплата, prosto прямо тощо. Тому варто студентам відштовхуватися не лише від власних вражень та тлумачень, а подібні слова вчити та знати їхнє значення, щоб не виникло суперечностей.

Для формування риторичної компетенції доцільно використовувати на заняттях польської мови елементів риторики, адже не у всіх ВНЗ риторика є самостійним предметом. Це можливо насамперед із засвоєнням студентами елементарних знань про риторику, ознайомлення 3 технікою публічного мовлення, етапів виступу, вмінь аргументувати та доводити свою думку, правил проведення дебатів.

Зокрема, вивчаючи певну тему 3 польської мови, наприклад, починаючи 3 елементарних «Moja rodzina», варто не лише використовувати такий вид роботи, як написання твору, але й усне висловлювання кількох студентів про свою сім'ю для тренування свого мовлення. Згодом, коли словниковий запас стане більшим і студентиполоністи зможуть більше сказати польською мовою, можна повноцінно використовувати такий прийом, як побудова публічних виступів на певну тему. Проте спочатку варто аналізувати зразки польського публічного мовлення (визначення структурних частин, аналіз інтонаційних особливостей тексту), це можна робити як за допомогою аудіо-, так i відеозаписів, зокрема, прослуховування записів з промовами, перегляд фільмів, телепередач, де можна простежити особливості публічних виступів. Після аналізу, коли студенти розуміють, як будувати публічний виступ, які помилки варто не допускати у промовах, потрібно вчити складати ескіз промови, iї побудову. Після цього вже можна виголошувати публічний виступ на задану тему.

Цікавим видом роботи під час вивчення польської мови $\epsilon$ моделювання комунікативних ситуацій, або так звані рольові ігри (наприклад, «Która godzina?», «W restauracji», «Gdzie jest moja rodzina?», «Sklep spożywczy»), що допомагають набувати досвіду. Наприклад, комунікаційна гра «Gdzie jest moja rodzina?» полягає в тому, що викладач поділяє групу на кілька сімей. Кожному зі студентів роздаються картки, де вказано основну інформацію про них. За допомогою питань один до одного варто знайти своїх членів сім’ї. Цікавими видами роботи є дебатні ігри, що дозволять висловлювати власні думки щодо актуальних тем, проте спочатку варто ознайомити з правилами проведення дебатів, щоб згодом не виникало непорозумінь та конфліктів, викладачеві також варто вчити формувати аргументи для дебатів на вказану тему, продумувати можливі аргументи, що підтверджують чи заперечують думку. Необхідно також студентам створювати та представляти перед аудиторією презентації, що допомагають наочній демонстрації свого виступу та значно полегшують сприймання та подання інформації.

Ще одним ефективним засобом для формування риторичної компетенції є вивчення скоромовок. Адже скоромовки розвивають мовлення, допомагають кращому засвоєнню фонетичних особливостей мови. Для філолога це є невід'ємним компонентом у тренуванні вимови. Ось кілька скоромовок для зразка: 1. Czarna krowa w kropki bordo żarła trawę kręcąc mordą. 2. A jej córka ryżo-raba zdarła rogiem korę z graba. 3. Czy się Czesi cieszą, gdy się Czesio czesze? 4. Czy tata czyta cytaty z Tacyta? 5. Drabina z powyłamywanymi szczeblami. 6. Jerzy nie wierzy, że na wieży jest dużo jeży. 7. Pchła pchłę pchała, pchła płakała. 8. Płynął buk przez Bug. Dałby Bóg, żeby buk przepłynął przez Bug. 9. Pojedziemy na Pomorze, może ono nam pomoże. 
Не менш важливим $є$ також вивчення віршів польською мовою, що не лише покращує пам'ять студентів, але і загалом збагачує словниковий запас.

Доречним видом роботи може бути попереднє укладання словника для виступу, структурними елементами якого є: польські слова та крилаті вислови, фразеологізми; фахова лексика.

Створення яскравих композиційних елементів (вступів, висновків) виступів на певні теми сприяє виробленню у студентів умінь реалізації мовних завдань.

Потрібним видом роботи з формування риторичної компетенції є робота з текстами: аналіз структурних елементів тексту, виокремлення виражальних засобів, редагування текстів, написання переказів. Звичайно, для успішного володіння мистецтвом слова потрібними є знання структурних елементів виступу, опрацювання необхідних джерел, грунтовна теоретична підготовка. Та не менш важливою умовою вдалого виступу $\epsilon$ правильність, точність, багатство мовлення.

Студентів варто зацікавити в самостійній роботі, адже неможливо охопити всі питання на занятті польської мови, саме тому студентам необхідно опрацьовувати теоретичний матеріал та поглиблювати свої знання 3 риторики, виконувати вправи 3 покращення мовлення, вчити вірші, скоромовки, проглядати публічні виступи та аналізувати ïx.

Набута студентами-філологами під час навчання у ВНЗ філологічна освіченість уможливлюватиме високий рівень подальшої професійної самоосвіти, сприятиме реалізації фахових знань у продуктивні й цивілізовані способи мисленнєво-мовленнєвої діяльності, сприятиме формуванню комунікативної та риторичної культури наукової та професійної еліти.

Отже, це лише коротка розвідка на шляху подальшого вивчення всіх можливостей формування риторичної компетенції. Адже філологу варто бути зразком для наслідування, відповідати вимогам часу і професії, бути всебічно освіченим, мати креативне мислення, високий рівень вузькопрофесійної та мовно-риторичної компетентності. Саме тоді риторична компетенція сприятиме формуванню у ВНЗ особистості гуманітарія ХХІ століття.

\section{Література}

1. Артамонова Е. П. Формирование иноязычной коммуникативной компетенции у будуших учителей иностранного языка на основе социокультурного подхода : дис. ... канд. пед. наук : 13.00.08 / Е. П. Артамонова. - Москва : РГБ, 2003. - 175 с. 2. Бацевич Ф. С. Основи комунікативної лінгвістики: [підручник] / Ф. С. Бацевич. - Київ : ВЦ «Академія», 2004. - 324 c. 3. Лобас Н. Mów po polsku. Розмовляй польською мовою / Н. Лобас. Тернопіль : Крок, 2010. - 194 с. 4. Онуфрієнко Г. С. До проблеми формування мовнориторичної компетентності як невід'ємної ознаки освіченості і чинника професіоналізму / Г. С. Онуфрієнко // Дошкільна освіта. - 2008. - № 2 (20). - C. 62-68. 5. Pelc T. Teraz polski. Gry i ćwiczenia komunikacyjne. Podręcznik dla nauczycieli języka polskiego jako obcego / T. Pelc. - Lódź : WING, 1997. - 180 c. 